\title{
The Acceptance and Interest of Students in Using Virtual Reality (VR) for Learning Mathematics
}

\author{
C. N. Saniyyati ${ }^{1}$, N. Razali ${ }^{1, *}$, H. Othman ${ }^{1}$, Nazatul Aini Abd Majid ${ }^{2}$ \\ ${ }^{1}$ Department of Engineering Education, Faculty of Engineering and Built Environment, Universiti Kebangsaan Malaysia, UKM, Bangi, \\ Selangor 43600, Malaysia \\ ${ }^{2}$ Faculty of Information Science \& Technology, Universiti Kebangsaan Malaysia, UKM, Bangi, Selangor 43600, Malaysia
}

Received March 2, 2020; Revised October 27, 2021; Accepted November 23, 2021

\section{Cite This Paper in the following Citation Styles}

(a): [1] C. N. Saniyyati, N. Razali, H. Othman, Nazatul Aini Abd Majid, "The Acceptance and Interest of Students in using Virtual Reality (VR) for Learning Mathematics," Universal Journal of Educational Research, Vol. 9, No. 12, pp. 1949 - 1961, 2021. DOI: 10.13189/ujer.2021.091207.

(b): C. N. Saniyyati, N. Razali, H. Othman, Nazatul Aini Abd Majid (2021). The Acceptance and Interest of Students in using Virtual Reality (VR) for Learning Mathematics. Universal Journal of Educational Research, 9(12), 1949 - 1961. DOI: 10.13189/ujer.2021.091207.

Copyright@2021 by authors, all rights reserved. Authors agree that this article remains permanently open access under the terms of the Creative Commons Attribution License 4.0 International License

\begin{abstract}
Nowadays, Virtual Reality (VR) is one of the new technologies that have been used in learning session that have a positive impact on the students. This article is intended to study the students' acceptance and interest in the use of VR in learning Mathematics. This study involves 37 students, of whom are 15 male students and 22 female students with age range of 15 and 16 years from Sekolah Menengah Maahad Tahfiz Ilmuan (SMITIN) located in Bangi, Selangor. The module that contains 13 questions and 1 set of questionnaires is used to collect the research data. The findings reveal that majority of the students show good results in the use of VR as learning tools in the lesson, whereby $89 \%$ of them got grade $\mathrm{A}$ in the task whilst the rest of them got grade A-. These technologies have a positive impact on the students in understanding Mathematics. Furthermore, the findings show that the usage of VR in the group can not only help improve students' social skills in doing tutorial in the class but also increase their interests in learning Mathematics. The implementation of VR application has a positive impact on the students in learning Mathematics with the help of their teachers and parents. Nevertheless, parents need to control the usage of the gadgets.
\end{abstract}

Keywords Virtual Reality (VR), Active Learning Method, Passive Learning Method, Problem Based Learning Method

\section{Introduction}

Knowledge and information can be found through different media. There are two types of learning that have been implemented in the education which are passive learning method and active learning method. Passive learning method is a method that students are not visibly doing anything, except watching, listening, or reading, which is a teacher-centered learning method [1]. This process creates convergent thinking, where a given question typically has only one right answer. Furthermore, according to Kikuchi [2], passive learning method depends only on the teachers to solve and explain the problems and students are only required to listen and write all the answer. It only required one-way learning method between students and teachers. This method used face-to-face delivery resources through the use of teaching space and seminar rooms. It entails the physical presence of learners in the rooms to learn the subject [3]. Besides passing the information to the students, that method encouraged people to interact and learn from other students [4].

However, passive learning method may seem good, but it is difficult to be done because of the limited space and time. There are many benefits of passive learning method but teaching a lot of students requires bigger spaces and rooms and travel [5]. Furthermore, this method is known to be costly, considering that the students are required to attend special class with additional cost on the books and teaching material [6]. That's why nowadays this method is 
not necessarily effective for students [7], [8]. Previous research and studies have shown that [9], students may struggle to solve a given task and incompetent of recalling given ideas if they rely only on lecturers.

Many institutions are still using these ineffective and non-interactive styles which result in a lack of interest among learners. Thus, in order to help students improve their learning journey, educators are encouraged to search for better approaches and learning styles [8]. Most likely students are in the passive recipients of knowledge rather than being involvedly active in the classroom [10] because the students only listen and respond to teacher's lectures, and repeat the information provided earlier by the teacher [11].

Based on the study performed, active learning method are preferred compared to passive learning method in the education system. Active learning method is a method that require student's participation in the class. According to [12], the two core elements in the active learning method are introducing exciting student's activity and promote student engagement in the class. Students enjoy their lesson in the class if they involve all the activities in the classroom. They understand what they learn, discuss and present and also improve their social skills in terms of interacting with other people. From this method, there will be multi-answer from one question and there is no right or wrong for the answer depends on how they explain the answer [13]. Besides that, active learning requires students' participation in applying knowledge rather than memorizing the facts and they know how to collaborate and discuss with other peers [14]. There are 3 approaches in active learning method which are cooperative learning method, problem based learning and collaborative learning method.

Cooperative learning (CL) method has been introduced to develop communication skills, self-developments and all good skills between students in the classroom. This method ensures students meaningfully and enthusiastically involved in their learning, reaching up to their potential [15]. It is the approaches that students possessing different levels of capability work together to make their effort in small groups to achieve a purpose, and maximize their personal potential and learning. Besides that, CL is a good learning approach to implement because of its positivity relationship between learners, as it can reduce peer competition and make a good teamwork [16], [17]. According to the previous research, significantly improvements in students' behavior can be seen. They matured in decision making and improved their interpersonal relationships when using CL as learning method compared to competitive and individualistic learning process [18].

In addition, Problem Based learning (PBL) method is also the approach that can improve academic skills, problem solving and communications skills among students. Similar to CL, PBL required a small group of students to solve the problems in academic curriculum without the tutor [19], [20]. Both methods need the initiative from students to progress through the project as well as for their own learning [21]. The main goal of PBL is to help the students gain knowledge from attending the problem and focus on the process to handle the problem. It has few steps to think which are digging the information about the problem, discovery of topics to be explored and also emerging of the strategies to solve problems [22]. Problem-based learning is a special learning because the focus of learning is on the problem and learning experience in real life. Hence, it also improve the critical thinking skills of the students and teamwork skills [22],[23].

Collaborative learning method has also been introduced to improve the passive learning method in student's education. More senses involve sound, touch, emotions and sight, as it can be recognized as an important part of an education system [24]. There are more than two learners work and learn together to solve the assignments in CL [25]. Students who are involved in CL are responsible for both their own learning and their colleagues' learning. Thus, the success of one student helps other students to be successful, too [26], [27]. Collaborating learning approaches make active involvements, interactions, evaluations, swapping ideas and experiences between students and increased their interests while promoting critical thinking [27]. The ultimate purpose of the approaches is to make students more appreciate and enjoy the subjects as well as improves their social skills and capable to solve assignments in a group. As we can see, lecturer will become a facilitator, a consultant when conflict occurs, and an observer in a group discussion [28], [29].

The improvement of modern information technology can expand CL approach become i) among students themselves and ii) students and teachers [30]. This new approach is known as a Computer-Supported Collaborative Learning (CSCL) [8]. According to this approach, with the help of the technology and gadget, students can improve their knowledge and learning [8]. In order to enhance the smooth of learning journey of students, educators are looking forward to implement new technologies in their classrooms because it can easily attract students to improve their academic performances [31]. The emergence of the AR and VR have a great impact on the coaching and learning process also create new ways to teach students and make the learning process livelier and more interesting [32].

Interactive technology for educational system is emerging at an amazingly fast rate, and advances in virtual reality (VR) that have led to many possible new applications [32]. VR can be described as "The use of computer modeling and simulation that makes a person to interact with an artificial three dimensional (3D) visual or other sensory environment” [33]. Furthermore, VR can allow students to see and interact with virtual surroundings 
and objects [32]. It can be delivered through a headset, which lets the students to feel objects and receive the 3D environment. Thus, students are totally engrossed in the virtual environment, as it replaces the physical environment around them [34]. As we can see, VR is a real-time immersive simulations through digital graphics and transport users to a fully world environment [35].

VR is classified into two major types of level of interaction which are immersive VR environment and non-immersive VR environment [36]. Immersive VR environment are presented on bigger size screen or through head mounted display unit include special computer hardware which are suits, gloves, paddles and high-end computer classifications [36]. In contrast, non-immersive VR computer simulation is characterized based on a conventional personal computer, including touch screen, ergonomic keyboard, joystick and mouse [36].

\section{Methodology}

\subsection{Design}

The VR Mathematics Workshop is part of the Faculty of Engineering and Built Environment (FKAB) Universiti Kebangsaan Malaysia, UKM - led workshop to encourage the students' interest in Mathematics. This quantitative research was held to improve the understanding of students in Mathematics with the help of teaching tool which is Virtual Reality (VR).

The students participate in this well-planned hands-on activity based on the module. Facilitators have developed the module that contains 'VR Math' application guide. "VR Math" application is one of the VR application systems that can be used to learn Mathematics, as shown in Figure 1.

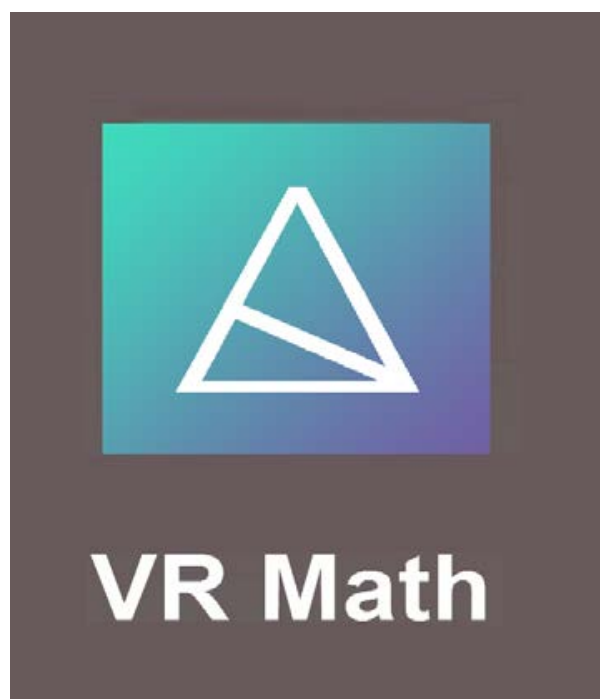

Figure 1. VR Math application

\subsection{Participants}

37 students from Sekolah Menengah Integrasi Tahfiz Ilmuan (SMITIN), Bangi Malaysia were invited to participate in the program. 9 small groups of 4 students were given the task and a questionnaire. The demographic profile in Table 1 shows 15 male students and 22 female students who were 15 and 16 years old were involved in the program.

Table 1. Demographic profile

\begin{tabular}{|c|c|c|}
\hline Gender & Frequency & $\%$ \\
\hline Male & 15 & 40.54 \\
\hline Female & 22 & 59.46 \\
\hline Total & 37 & 100 \\
\hline
\end{tabular}




\subsection{Instrumentation}

Table 2. Details of the questionnaire's Likert Scale

\begin{tabular}{|c|c|}
\hline $\begin{array}{c}\text { Number of } \\
\text { Scale }\end{array}$ & Details \\
\hline 1 & Strongly Disagree \\
\hline 2 & Disagree \\
\hline 3 & Neutral \\
\hline 4 & Agree \\
\hline 5 & Strongly Agree \\
\hline
\end{tabular}

Quantitative data for this research was collected through survey questionnaire. A set of questionnaires in the form of Likert Scale was given to the students regarding their opinions towards the use of VR in Mathematics subject.
The five Likert Scales used such as “ 1 " - "Strongly Disagree”, "2"- "Disagree”, "3" - "Neutral”, “4” "Agree", and "5" - "Strongly Agree". The details of the Likert scale from 1 to 5 are tabulated in Table 2. The descriptive data analysis was analyzed by using Rasch Measurement Model software (Winstep software). The reliability of the instrument was high with Cronbach's Alpha value of 0.85 .

\subsection{Procedure}

The workshop session was conducted on 7 November 2019 that focused on the usage of Virtual Reality (VR) in Mathematics. A total of 9 groups of students were formed and actively involved during the workshop session. The group members were required to works cooperatively with their team to complete the module.

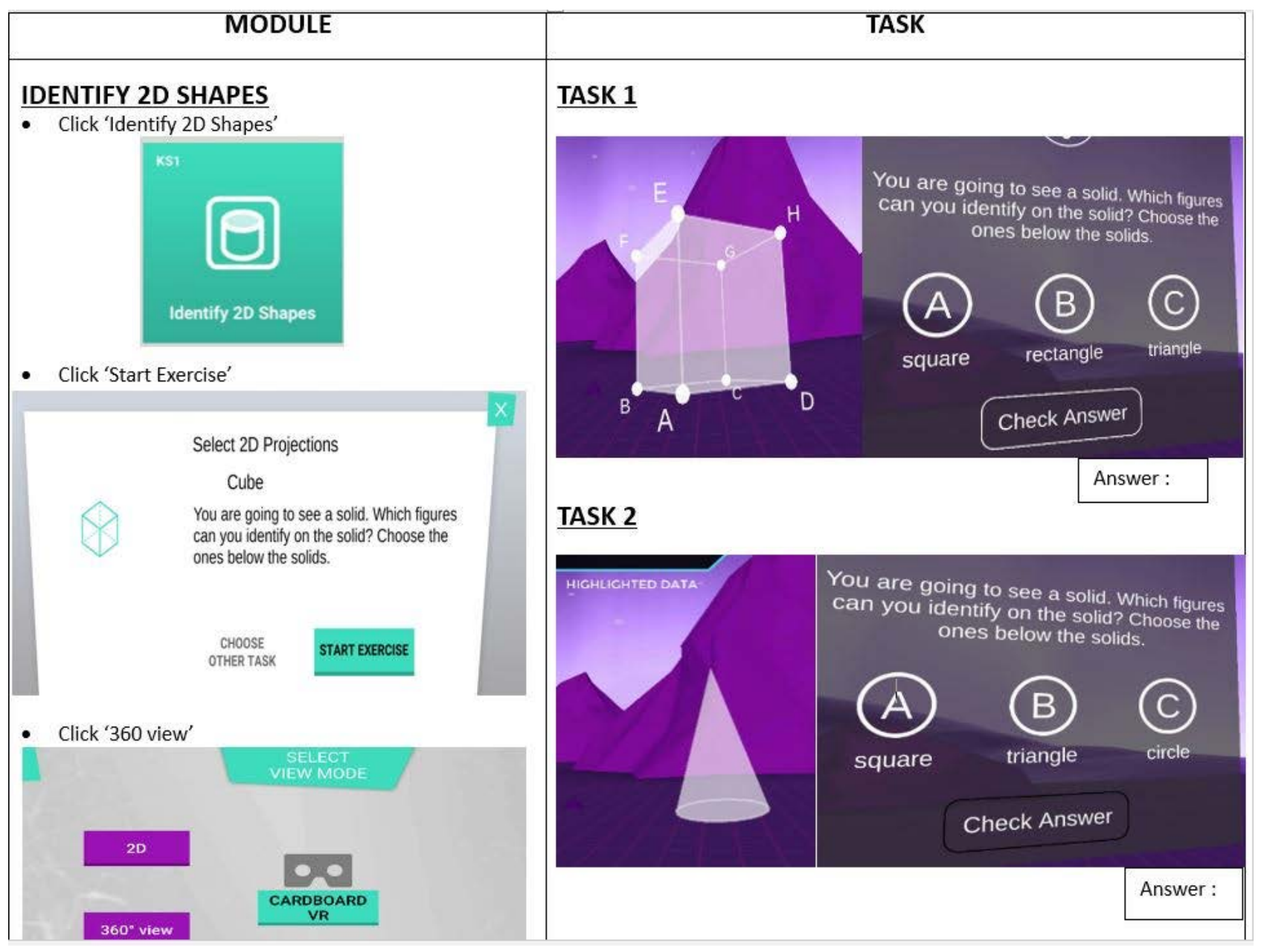

Figure 2. Example of questions in the module 
A short briefing was conducted by the Head of the workshop to provide the fundamental knowledge on how to use the VR Math application in the smartphone and VR glasses. Each student needed to install the VR Math application in their smartphone in order to answer the 13 questions provided in the module. Figure 2 shows the example of questions in the module. 9 units of VR glasses were given to each of the group to let them try and answer the questions in the module. At the end of the workshop, the students need to complete the questionnaire given by the facilitator. The details of the questionnaire are shown in Table 3.

Table 3. Details of the questionnaire

\begin{tabular}{|c|l|}
\hline $\begin{array}{c}\text { Number of } \\
\text { Question }\end{array}$ & \multicolumn{1}{c|}{ Details of the Question } \\
\hline Question 1 & $\begin{array}{l}\text { Do VR applications help students understand } \\
\text { the Mathematics subject? }\end{array}$ \\
\hline Question 2 & $\begin{array}{l}\text { Do you want VR applications to be one of the } \\
\text { topics in your school's Mathematics } \\
\text { curriculum? }\end{array}$ \\
\hline Question 3 & $\begin{array}{l}\text { As a student, do you want your parents to help } \\
\text { with the use of VR application especially in } \\
\text { Mathematics subject? }\end{array}$ \\
\hline Question 4 & $\begin{array}{l}\text { Do you believe that applications such as VR } \\
\text { can stimulate students' interest in current } \\
\text { technological developments? }\end{array}$ \\
\hline Question 5 & $\begin{array}{l}\text { Are you more motivated to learn Mathematics } \\
\text { subject with the use of VR applications? }\end{array}$ \\
\hline
\end{tabular}

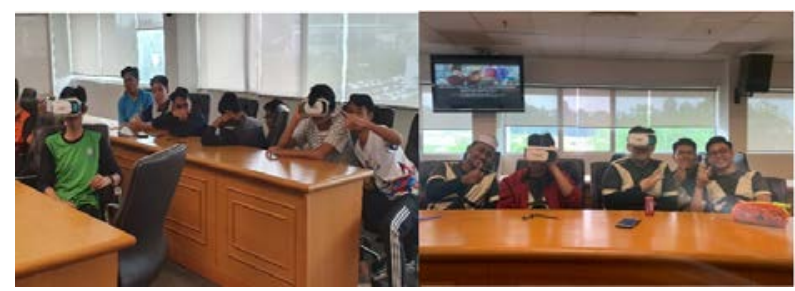

Figure 3. Application of VR glasses in the workshop

Figure 3 shows the application of VR glasses in the workshop as one of the learning tools. The students had answered all the questions using the "VR Math" application, as shown in Figure 4. At the end of the workshop, the students needed to submit the module together with the answer and the questionnaire.

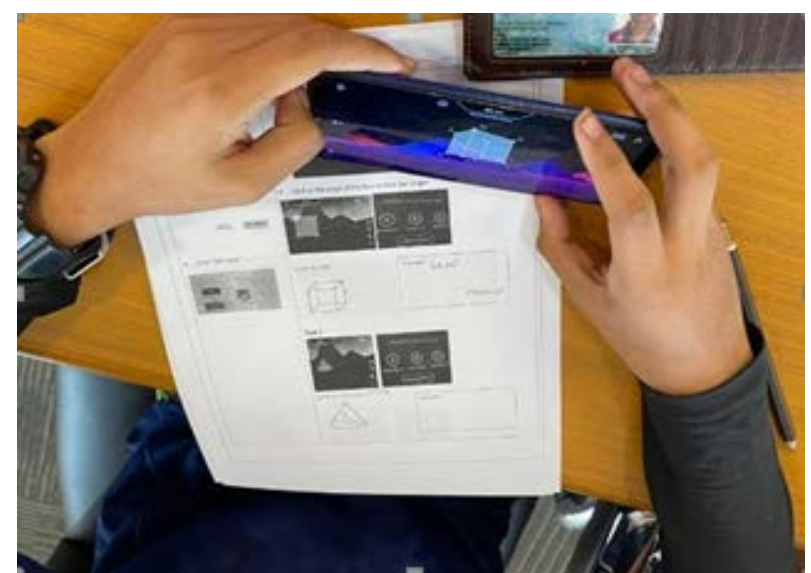

Figure 4. "VR Math” application

\section{Results and Discussions}

Figure 5 shows the total marks that each of the students achieved in the module given. Total marks in percentage (\%) for 37 students are shown in Figure 6 as below. As observed, most of the students got above 30 out of 39, which is above $77 \%$ marks. The highest mark is 39 out of 39 , which is $100 \%$ marks and there are 14 students achieving full marks. The overall percentage marks for 37 students is shown in Figure 7. According to Figure 7, there are 17 students who scored $97.5 \%, 9$ students scored $92.5 \%$, 7 students scored $87.5 \%$, followed by 4 students achieved $77.5 \%$ in the task given. Moreover, all the marks that achieved are categorized into grades which are 33 out of 37 (89\%) students scored A and only 4 students scored A- as shown in Figure 8. It shows that all the students understood clearly about the task given and they enjoyed the subject that used virtual reality (VR) as a learning tool. These technologies have an impact on students' attitude towards that Mathematics subject. 


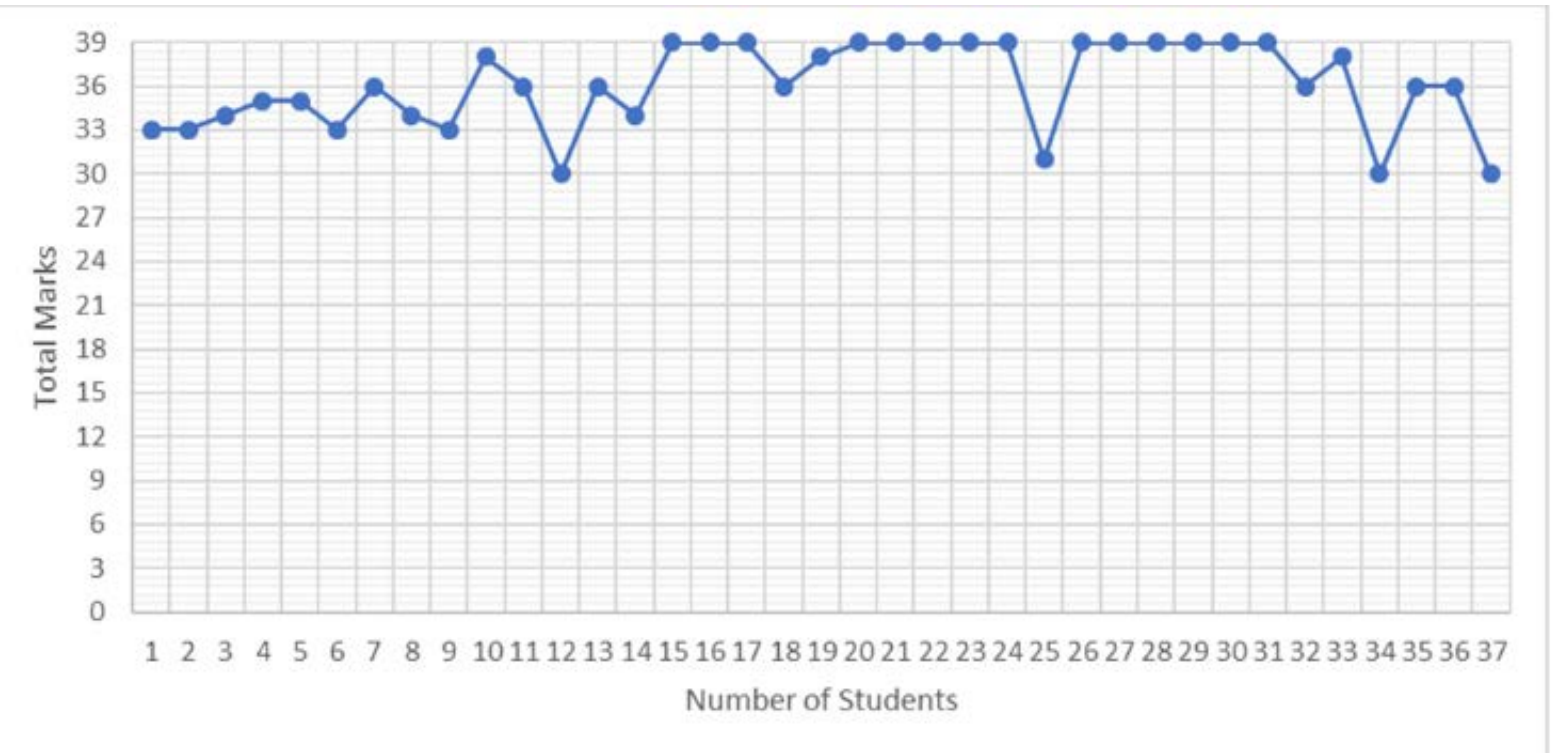

Figure 5. Total Marks for 37 students

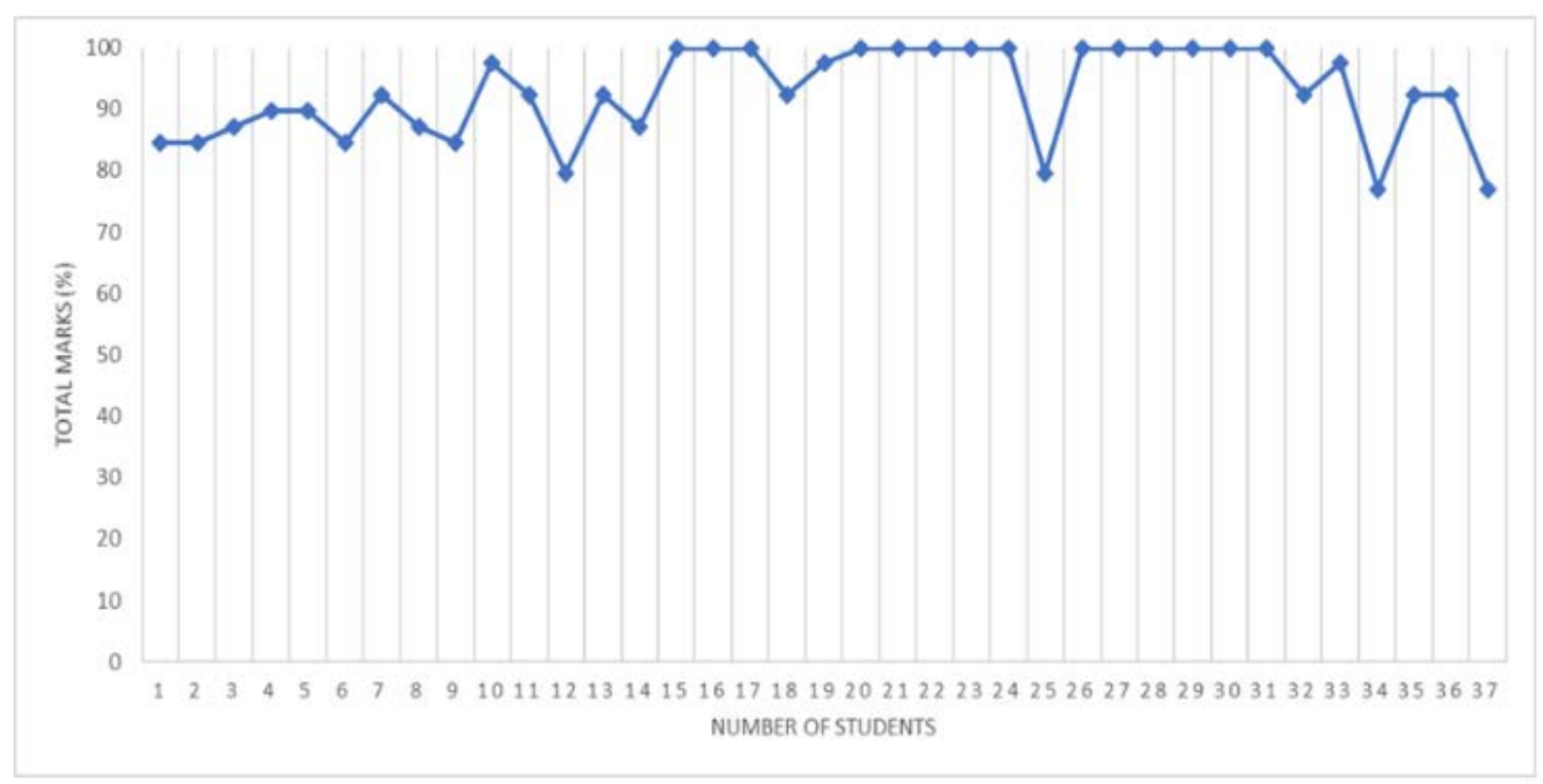

Figure 6. Total Marks (\%) for 37 students 


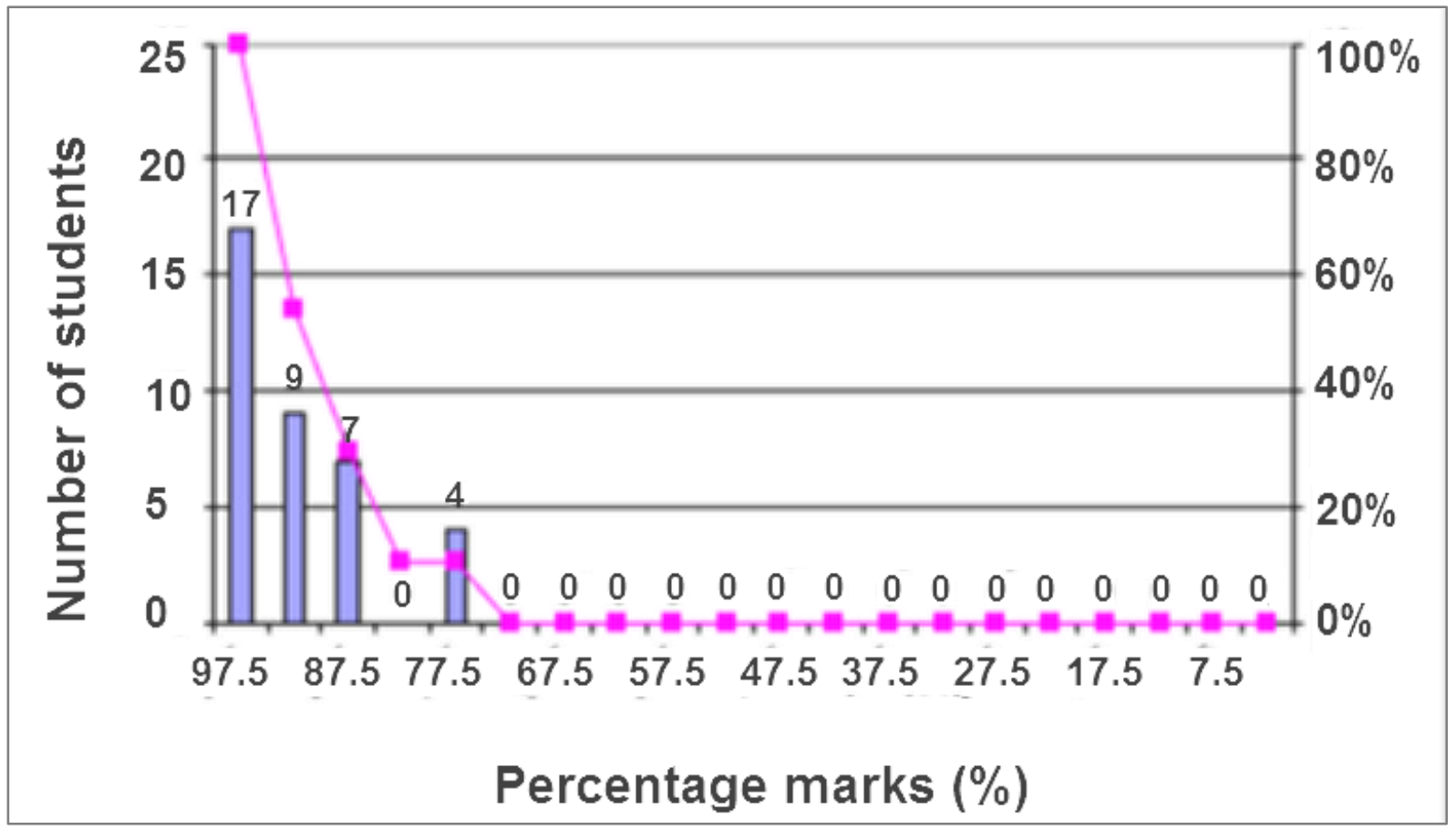

Figure 7. Overall percentage marks for 37 students

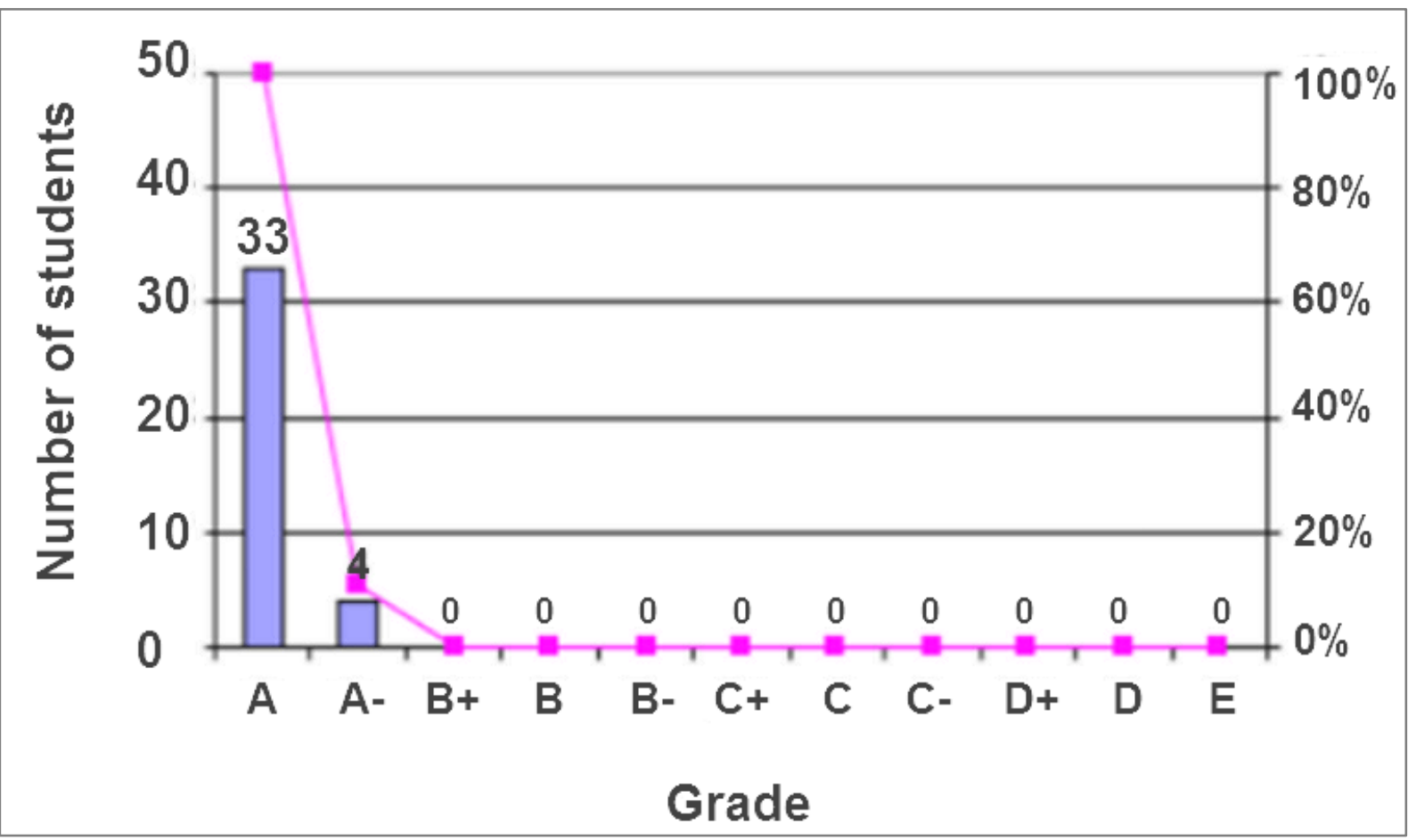

Figure 8. Overall grades for 37 students 


\begin{tabular}{|c|c|c|c|c|c|c|c|c|c|c|}
\hline \multirow{2}{*}{ PERSON } & 37 & INPUT & 37 MEA & SURE & & \multicolumn{3}{|c|}{ INF IT } & \multicolumn{2}{|c|}{ OUTFIT } \\
\hline & TOTAL & COUNT & \multicolumn{2}{|c|}{ MEASURE } & REALSE & & IMNSQ & ZSTD & OHNSQ & \multirow{2}{*}{$\begin{array}{r}\text { ZSTD } \\
.0\end{array}$} \\
\hline MEAN & 20.4 & 5.0 & \multirow{2}{*}{\multicolumn{2}{|c|}{$\begin{array}{l}2.22 \\
1.42\end{array}$}} & .84 & \multirow{2}{*}{\multicolumn{2}{|c|}{$\begin{array}{l}.98 \\
.57 \\
\end{array}$}} & \multirow{2}{*}{$\begin{array}{r}.0 \\
.9 \\
\end{array}$} & .96 & \\
\hline S.D. & 2.6 & .0 & & & .24 & & & & .56 & .91 \\
\hline REAL RMSE & .8 & 38 TRUE SD & 1.12 & SE & ARAT ION & 1.28 & PER & $0 \mathrm{~N}$ RE & IABILITY & | \\
\hline ITEM & 5 IN & IPUT & 5 MEASUI & BED & & & INF & & OUTF & I T \\
\hline & TOTAL & COUNT & MEA & SURE & REALSE & & I MNSQ & ZSTD & OHNSQ & ZSTD| \\
\hline MEAN & 151.8 & 37.0 & & .00 & .29 & & 1.03 & .1 & .96 & -.21 \\
\hline S.D. & 9.7 & .0 & & .78 & .65 & & .27 & 1.1 & .17 & .81 \\
\hline REAL RMSE & .3 & 30 TRUE SD & .72 & SE & ARATION & 2.43 & ITE & RE & IABILITY & .85 \\
\hline
\end{tabular}

Figure 9. Statistics Summary for Item and Person

Table 4. Overall data collected from the questionnaire survey

\begin{tabular}{|c|c|c|c|c|c|c|}
\hline \multirow{2}{*}{$\begin{array}{l}\text { Number of } \\
\text { Question }\end{array}$} & \multirow{2}{*}{ Item Description } & \multicolumn{5}{|c|}{ Response } \\
\hline & & $\begin{array}{l}\text { Strongly } \\
\text { Disagree }\end{array}$ & Disagree & Neutral & Agree & $\begin{array}{c}\text { Strongly } \\
\text { Agree }\end{array}$ \\
\hline Question 1 & $\begin{array}{l}\text { Do VR applications help students } \\
\text { understand the Mathematics subject? }\end{array}$ & $\begin{array}{c}0 \\
(0 \%)\end{array}$ & $\begin{array}{c}0 \\
(0 \%)\end{array}$ & $\begin{array}{c}13 \\
(35.1 \%)\end{array}$ & $\begin{array}{c}15 \\
(40.5 \%)\end{array}$ & $\begin{array}{c}9 \\
(24.3 \%)\end{array}$ \\
\hline Question 2 & $\begin{array}{l}\text { Do you want VR applications to be one } \\
\text { of the topics in your school's } \\
\text { Mathematic curriculum? }\end{array}$ & $\begin{array}{c}0 \\
(0 \%)\end{array}$ & $\begin{array}{c}1 \\
(2.7 \%)\end{array}$ & $\begin{array}{c}5 \\
(13.5 \%)\end{array}$ & $\begin{array}{c}19 \\
(51.4 \%)\end{array}$ & $\begin{array}{c}12 \\
(32.4 \%)\end{array}$ \\
\hline Question 3 & $\begin{array}{l}\text { As a student, do you want your parents } \\
\text { to help with the use of VR application } \\
\text { especially in Mathematics subject? }\end{array}$ & $\begin{array}{c}0 \\
(0 \%)\end{array}$ & $\begin{array}{c}3 \\
(8.1 \%)\end{array}$ & $\begin{array}{c}8 \\
(21.6 \%)\end{array}$ & $\begin{array}{c}18 \\
(48.6 \%)\end{array}$ & $\begin{array}{c}8 \\
(21.6 \%)\end{array}$ \\
\hline Question 4 & $\begin{array}{l}\text { Do you believe that applications such } \\
\text { as VR can stimulate students' interest in } \\
\text { current technological developments? }\end{array}$ & $\begin{array}{c}0 \\
(0 \%)\end{array}$ & $\begin{array}{c}0 \\
(0 \%)\end{array}$ & $\begin{array}{c}4 \\
(10.8 \%)\end{array}$ & $\begin{array}{c}8 \\
(21.6 \%)\end{array}$ & $\begin{array}{c}25 \\
(67.6 \%)\end{array}$ \\
\hline Question 5 & $\begin{array}{l}\text { Are you more motivated to learn } \\
\text { Mathematics subject with the use of VR } \\
\text { applications? }\end{array}$ & $\begin{array}{c}1 \\
(2.7 \%)\end{array}$ & $\begin{array}{c}1 \\
(2.7 \%)\end{array}$ & $\begin{array}{c}8 \\
(21.6 \%)\end{array}$ & $\begin{array}{c}15 \\
(40.5 \%)\end{array}$ & $\begin{array}{c}12 \\
(32.4 \%)\end{array}$ \\
\hline
\end{tabular}

The overall data collected from the survey are tabulated in Table 4. This workshop has received good responses from most of the students. They prefer to choose "Agree" and "Strongly Agree". Meanwhile, for Likert scale point "Disagree" and "Strongly Disagree", none responded to that answer.

Cronbach Alpha is generally used to measure the internal consistency reliability of the items. When Cronbach Alpha values exceed 0.7, it shows that the items have high internal consistency and reliability. As shown in Figure 9, the value of item reliability is 0.85 , exceeding the acceptable values (0.7). It shows that the items are adequate to measure the students' perception toward VR.

Figure 10 below shows the number of students' vote for each questionnaire scale in Question 1. From Figure 8, it shows that there are no students who strongly disagree and disagree for Question 1. Furthermore, 15 out of 37 (40.5\%) students agree and 9 out of 37 (24.3\%) students strongly agree that VR applications help them to understand mathematics because VR applications can attract students' attention to learn more about that subject.

In Question 2, the number of students' vote for each questionnaire scale are shown in Figure 11. There are 0 students who strongly disagree and only 1 student who disagree with that question. 19 out of 37 (51.4\%) students agree that VR applications are one of the topics in the school's Mathematic curriculum. From the results, it shows that virtual reality really can improve the student's knowledge and they enjoy learning the subject.

In addition, Figure 12 shows the number of students' vote for each questionnaire scale in Question 3. According to Figure 12, the result shows that 8 out of 37 (21.6\%) students vote for neutral and strongly Likert scale point. Nevertheless, half of the students which is 18 out of 37 (48.6\%) students agree that they want their parents to take part in the VR learning process. From this survey, it shows that the students need their parents' involvement throughout the learning process. Therefore, it is important for parents to spend their time together with the students throughout the learning process.

Moreover, the number of students' vote for each questionnaire scale in Question 4 is shown in Figure 13. Overall, $67.6 \%$, namely 25 out of 37 students strongly agree and 8 out of 37 (21.6\%) students agree that additional learning tools such as virtual reality can help stimulate students' interest in learning the subject. These VR technologies allow students to see and interact with the virtual environments and objects. In this new era, students 
prefer to explore new technology (VR) and if they combine it with the subject that they learn, it has an impact; for example, it prolongs the students' focus in learning process. They can see real things through the glasses and easily relate with the subject.

Lastly, Figure 14 shows the number of students' vote for each questionnaire scale in Question 5. Percentage of the students that agree and strongly agree are higher than the students that disagree and strongly disagree which is $73 \%$.
15 students agree and 12 students strongly agree that they are more motivated and enjoy learning Mathematics subject with the use of VR applications. It shows that VR have benefited the students in learning Mathematics. In addition, students can discuss with their friends how to use VR applications in the subject as well as improve their social skills and not only doing tutorial in the class. They can use their critical thinking and explore new things to solve the problems in the subject.

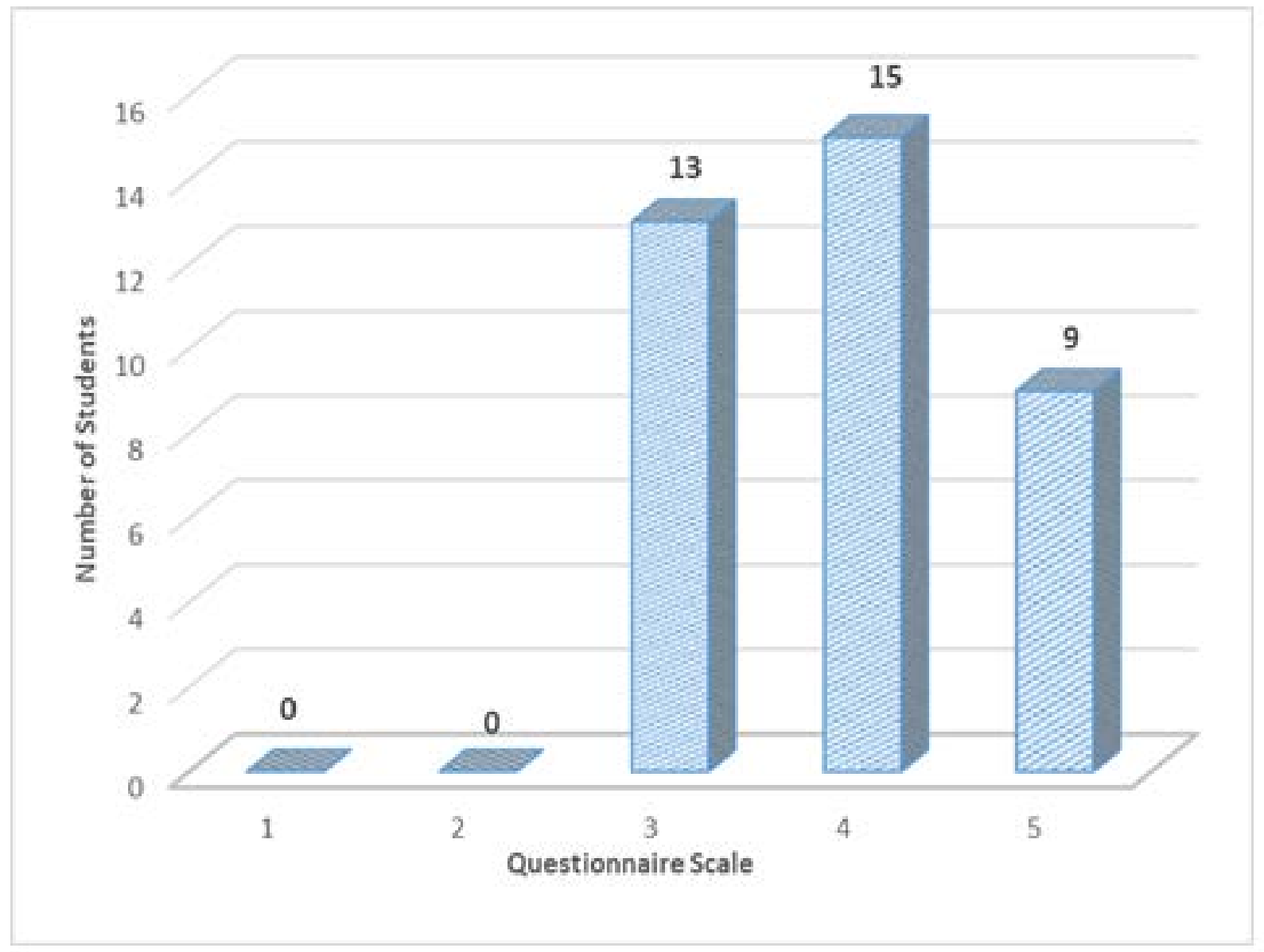

Figure 10. Number of students' vote for each questionnaire scale in Question 1 


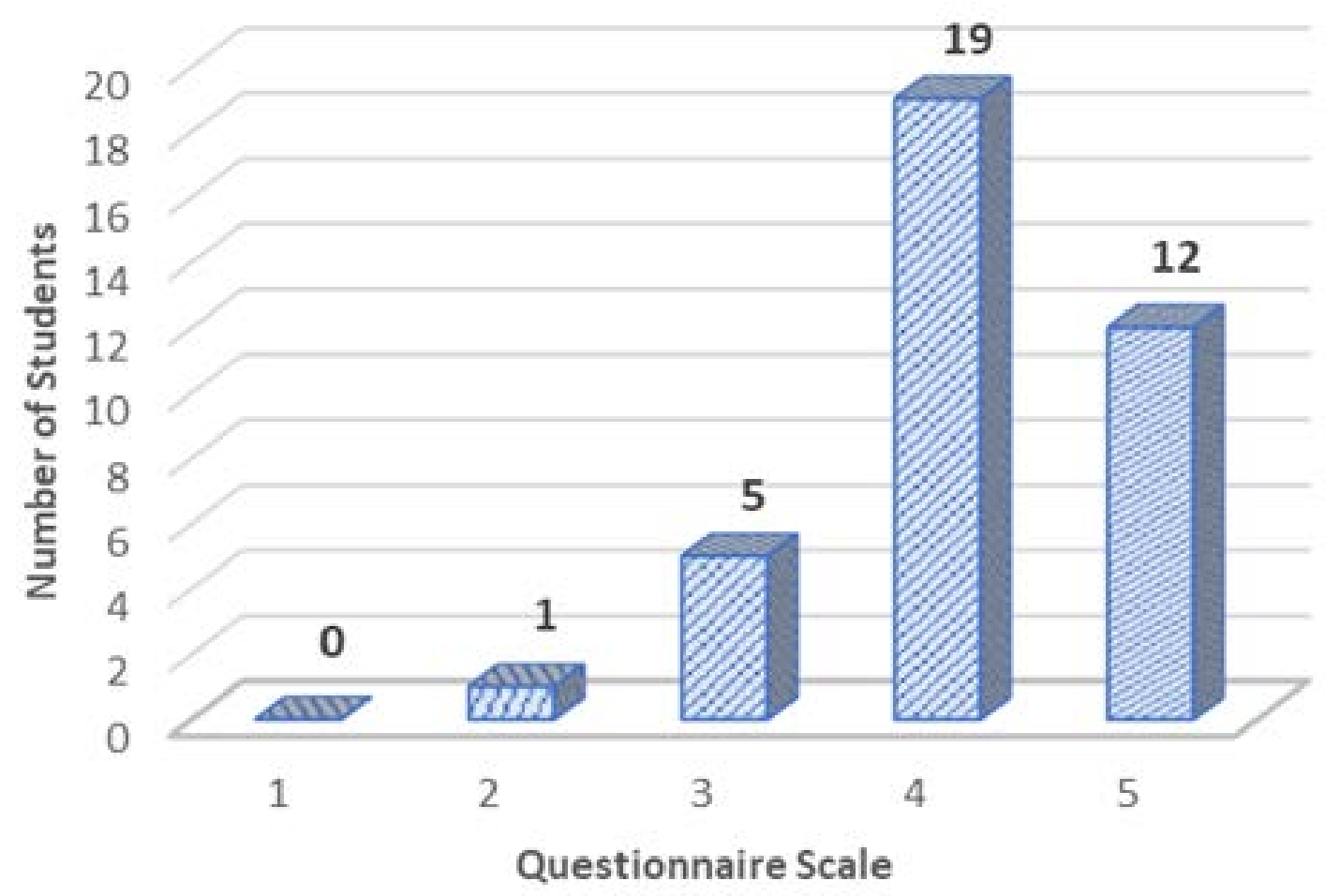

Figure 11. Number of students' vote for each questionnaire scale in Question 2

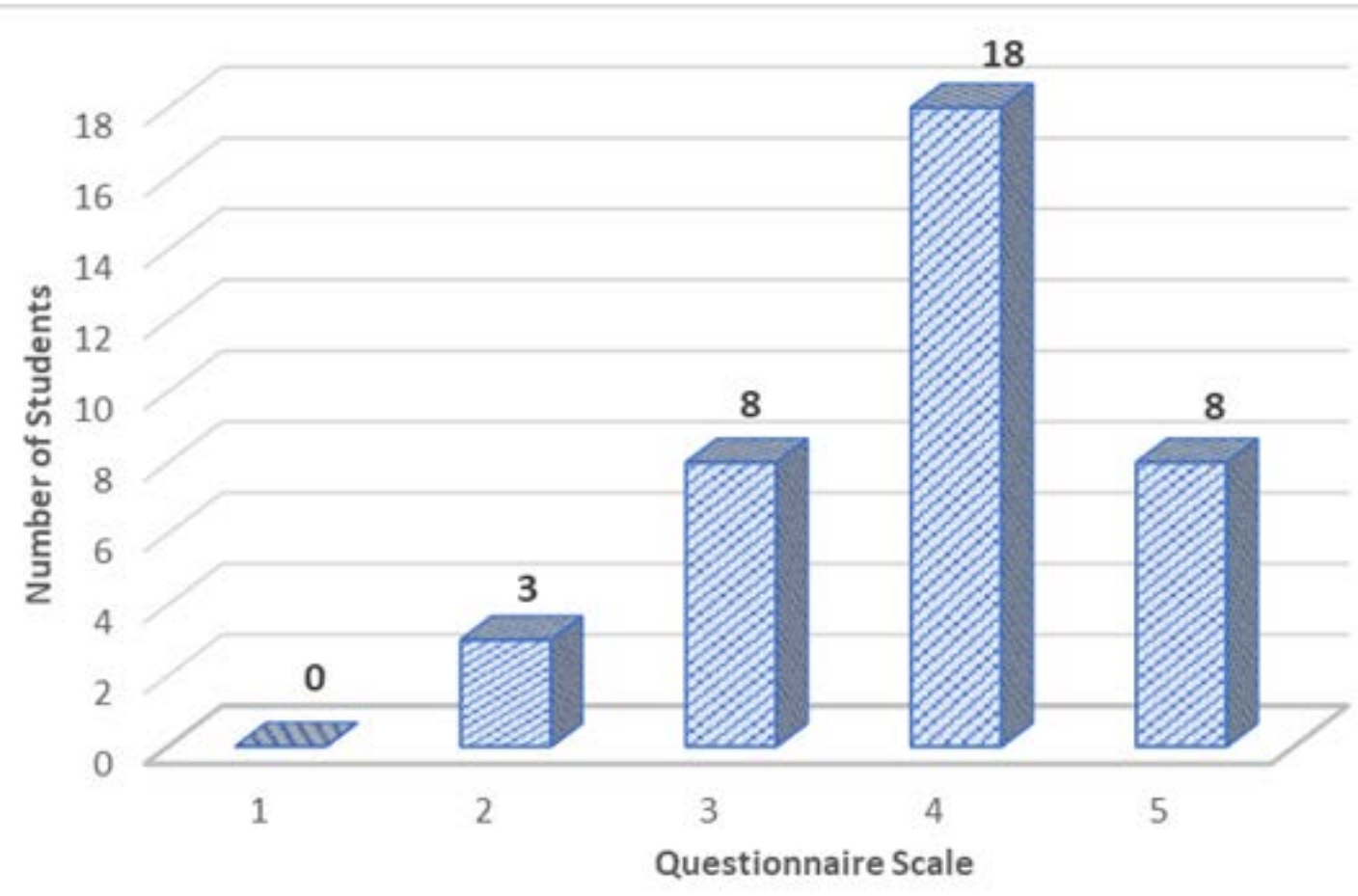

Figure 12. Number of students’ vote for each questionnaire scale in Question 3 


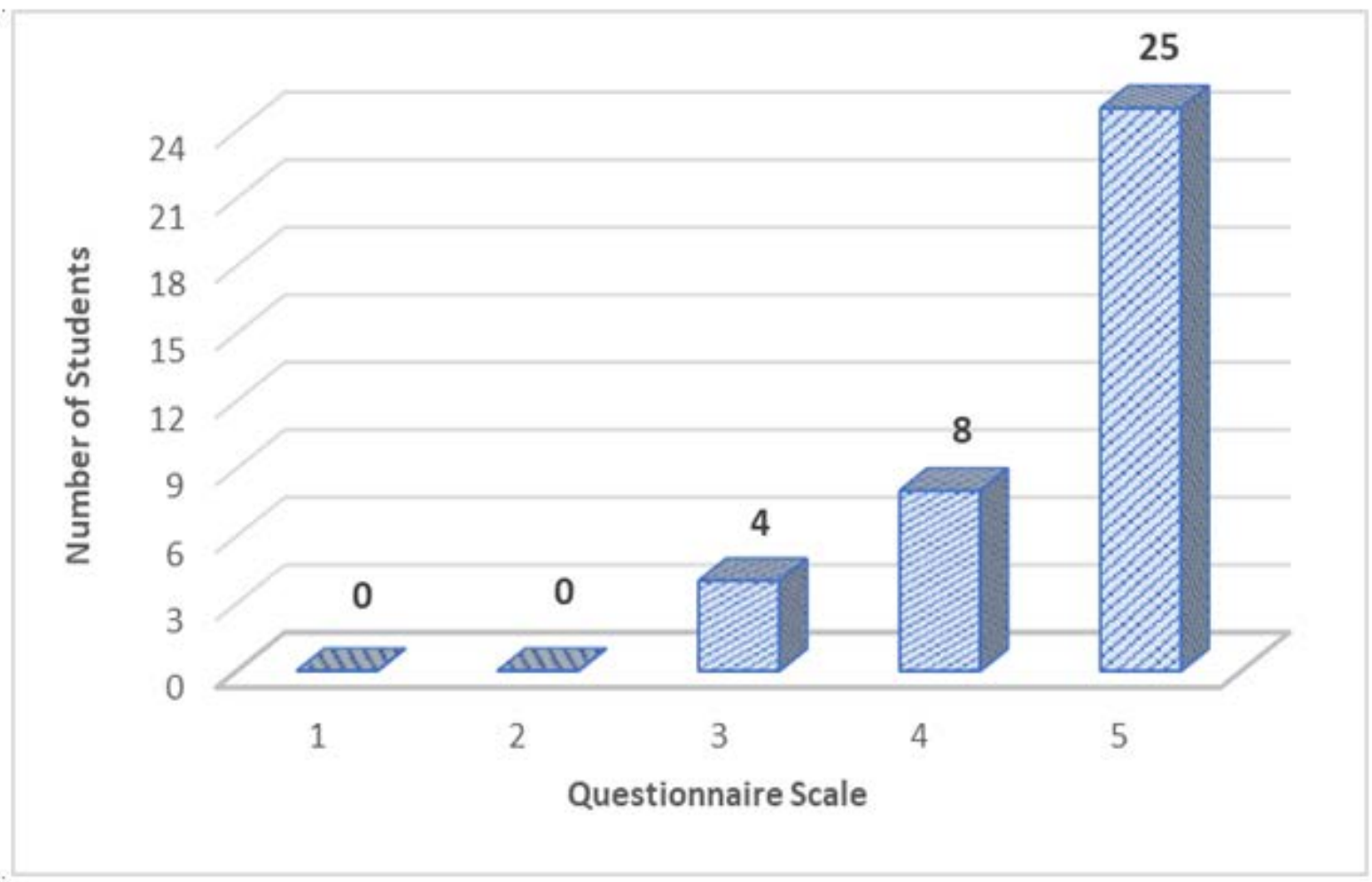

Figure 13. Number of students' vote for each questionnaire scale in Question 4

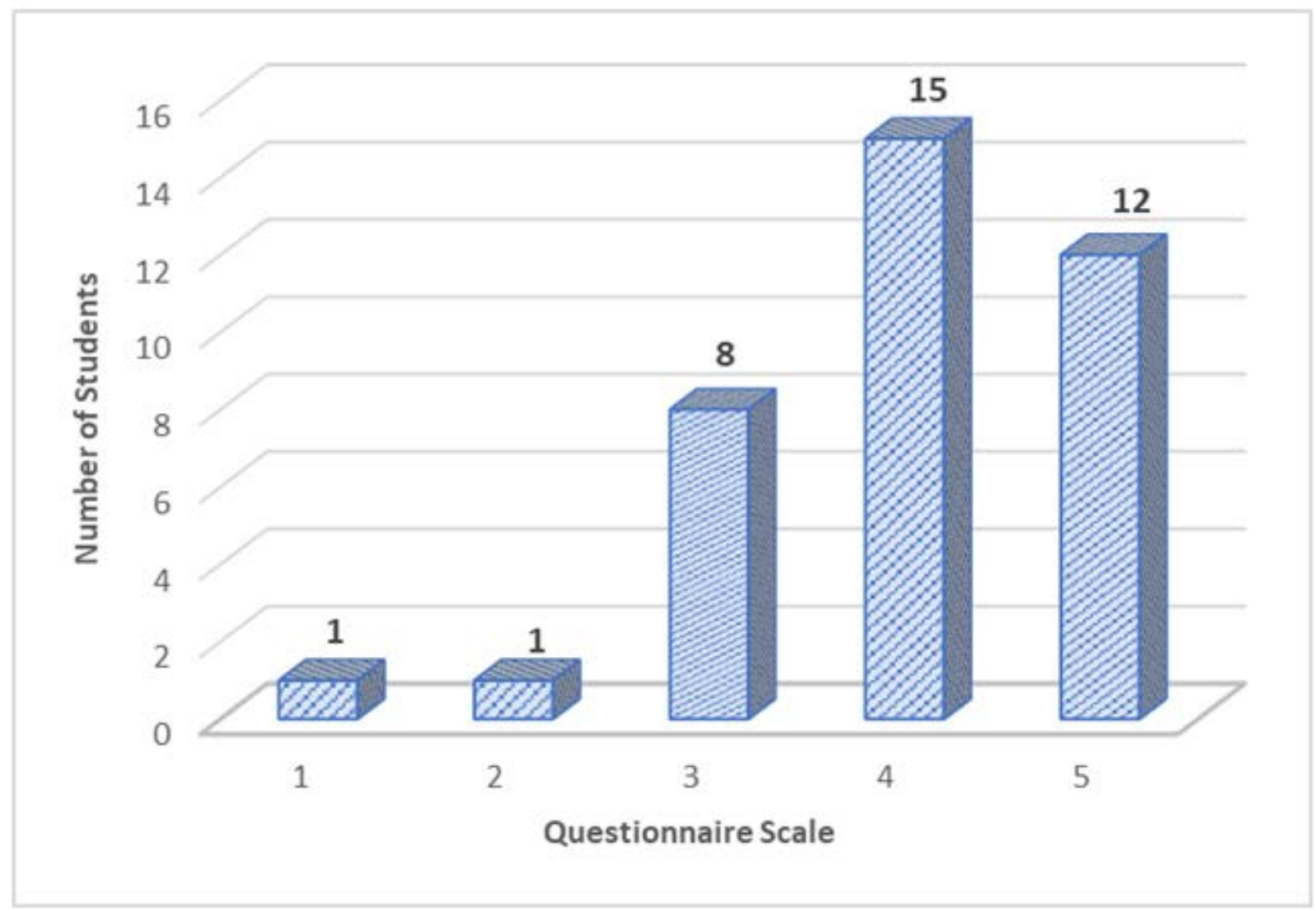

Figure 14. Number of students' vote for each questionnaire scale in Question 5 


\section{Conclusions}

VR Mathematics Workshop is one of the initiatives taken by FKAB, UKM as a learning support activity to improve the students' understanding and interests in Mathematics using virtual reality. Analysis done in this paper shows that the use of VR has benefited the students in terms of understanding the subject. Majority of the students got good results in the task given.

This paper reveals that throughout the workshop, most of the students agree that the usage of virtual reality has increased the students' interest in learning Mathematics. Students are more motivated to learn Mathematics and enjoy learning it with the involvement of their parents and teachers. The result of this study is in line with the results of the previous studies on students' interests and understanding in Mathematics. It is revealed that students' understanding and interests in learning mathematics were increasing [37, 38]. Therefore, the applications can increase the student's interests in learning Mathematics subject and they can discuss with their friends on how to use VR applications in the subject as well as improving their social skills in the class. They can use their critical thinking and explore new things to solve the problems in the subject when using VR applications.

To help more students to get good grades in the subject, the author believes that the implementation of VR application has a positive impact on the students with the help of their teachers and parents. Nevertheless, parents need to control the usage of the gadgets so that the students only use the gadgets in the classroom. They need to have time balance when using the gadgets and also do some outdoor activities to reduce the stress in the classroom. Overall, VR Mathematics workshop is considered as one of the Mathematics learning supports for students. With the help of facilitators and carefully constructed tasks and exercises, this workshop can improve the students' Mathematics performance. Students are more appreciative and willing to conduct more exercises during Mathematics workshop with the use of VR compared to the traditional learning activities. Objectively, this Mathematics workshop will create a better appreciation and awareness among students towards Mathematics education. However, this study was limited to the respected respondents and questions; therefore, a broader sample and questions are recommended for achieving better results.

\section{Acknowledgements}

The authors fully acknowledged University Kebangsaan Malaysia and the Ministry of Higher Education under the grant GPK-P\&P-2020-008 for the opportunity which makes this important research viable and effective.

\section{REFERENCES}

[1] M. B. Alejandra J. Magana, Camilo Vieira, “Characterizing Engineering Learners’ Preferences for Active and Passive Learning Methods,” vol. 61, no. 1, pp. 46-54, 2018.

[2] T. Kikuchi, S. Yamashita, M. Suzuki, K. Ozawa, H. Takahashi, and M. Kimura, "Comparative study of passive and active learning classes in basic mathematics training for electrical engineering," SII 2016 - 2016 IEEE/SICE Int. Symp. Syst. Integr., pp. 838-843, 2017.

[3] G. C. Alaneme, P. O. Olayiwola, and C. O. Reju, "Combining traditional learning and the E-learning methods in higher distance education: Assessing learners' preference," ICDLE 2010 - 2010 4th Int. Conf. Distance Learn. Educ. Proc., no. Guiton 1992, pp. 187-190, 2010.

[4] Y. Suo and Y. Shi, "Towards blended learning environment based on pervasive computing technologies,” Lect. Notes Comput. Sci. (including Subser. Lect. Notes Artif. Intell. Lect. Notes Bioinformatics), vol. 5169 LNCS, no. 2006, pp. 190-201, 2008.

[5] W. Kim, “Towards a Definition and Methodology for Blended Learning. In the Proceedings of Workshop on Blended Learning,” pp. 1-8, 2007.

[6] H. Sarjono, S. Candra, and N. J. Setiadi, “From traditional learning into e-learning: Comparing students response to promote e-learning in college education,” Proc. 2013 IEEE Int. Conf. Teaching, Assess. Learn. Eng. TALE 2013, no. August, pp. 7-11, 2013.

[7] R. E. Mayer, “The promise of multimedia learning: using the same instructional design methods across different media,” Learn. Instr., vol. 13, no. 2, pp. 125-139, 2003.

[8] D. N. Eh Phon, M. B. Ali, and N. D. A. Halim, "Collaborative augmented reality in education: A review," Proc. - 2014 Int. Conf. Teach. Learn. Comput. Eng. LATICE 2014, pp. 78-83, 2014.

[9] R. E. Mayer, "Multimedia learning: Are we asking the right questions?,” Educ. Psychol., vol. 32, no. 1, pp. 1-19, 1997.

[10] H. Othman, I. Asshaari, H. Bahaludin, N. M. Tawil, and N. A. Ismail, "Student's Perceptions on Benefits Gained from Cooperative Learning Experiences in Engineering Mathematics Courses,” Procedia - Soc. Behav. Sci., vol. 60, no. Cl, pp. 500-506, 2012.

[11] M. Galton, L. Hargreaves, C. Comber, D. Wall, and T. Pell, "Changes in Patterns of Teacher Interaction in Primary Classrooms: 1976 - 96,” Br. Educ. Res. J., vol. 25, no. 1, pp. 23-37, 1999.

[12] M. Prince, "Does Active Learning Work? A Review of the Research,” J. Eng. Educ., vol. 93, no. 3, pp. 223-231, Jul. 2004.

[13] B. M. Martyn, “Clickers in class,” Educ. Q., no. 2, pp. 7174, 2007.

[14] E. J. H. Spelt, H. J. A. Biemans, H. Tobi, P. A. Luning, and M. Mulder, "Teaching and learning in interdisciplinary higher education: A systematic review,” Educ. Psychol. 
Rev., vol. 21, no. 4, pp. 365-378, 2009.

[15] D. W. Johnson and R. T. Johnson, "Making cooperative learning work,” Theory Pract., vol. 38, no. 2, pp. 1-73, 1999.

[16] D. W. Johnson and R. T. Johnson, "Learning Together and Alone: Overview and Meta - analysis," Asia Pacific J. Educ., vol. 22, no. 1, pp. 95-105, 2002.

[17] R. E. Slavin, "Research on cooperative learning and achievement: What we know, what we need to know," Contemp. Educ. Psychol., vol. 21, no. 1, pp. 43-69, 1996.

[18] A. O. Akinbobola, “Enhancing students' attitude towards Nigerian senior secondary school physics through the use of cooperative, competitive and individualistic learning strategies,” Aust. J. Teach. Educ., vol. 34, no. 1, pp. 1-9, 2009.

[19] J. C. Perrenet, P. A. J. Bouhuijs, and J. G. M. M. Smits, "The Suitability of Problem-based Learning for Engineering Education: Theory and practice,” Teach. High. Educ., vol. 5, no. 3, pp. 345-358, 2000.

[20] J. E. Mills and D. Treagust, "Engineering Education, Is Problem-Based or Project-Based Learning the Answer," no. January, 2003.

[21] J. Uziak and V. P. Kommula, "Application of problem based learning in mechanics of machines course," Int. J. Eng. Pedagog., vol. 9, no. 1, pp. 68-83, 2019.

[22] A. M. Rashid, "Relationship between Learning Environment and Teamwork Skills among Final Year Students of Vocational Colleges," Univers. J. Educ. Res., vol. 8, no. 1982, pp. 104-111, 2020.

[23] M. S. Y. Hairun, Suparman, and Y. Hairun, “Analysis and design of PBL-based mathematics students worksheet to improve critical thinking skills," Univers. J. Educ. Res., vol. 8, no. 8, pp. 3310-3322, 2020.

[24] D. Pérez-López and M. Contero, "Delivering educational multimedia contents through an augmented reality application: A case study on its impact on knowledge acquisition and retention," Turkish Online J. Educ. Technol., vol. 12, no. 4, pp. 19-28, 2013.

[25] M. Laal, "Positive Interdependence in Collaborative Learning,” Procedia - Soc. Behav. Sci., vol. 93, pp. 14331437, 2013.

[26] K. Doymus, "Effects of a cooperative learning strategy on teaching and learning phases of matter and one-component phase diagrams,” J. Chem. Educ., vol. 84, no. 11, pp. 1857-
1860, 2007.

[27] A. A. Gokhale, “Collaborative Learning Enhances Critical Thinking,” J. Technol. Educ., vol. 7, no. 1, pp. 22-30, 1995.

[28] H. Pangestu, M. Karsen, and Y. U. Chandra, "Evaluation of Collaborative Learning Tools Implementation to Improve Learning Quality in Higher Education,” Proc. 2019 Int. Conf. Inf. Manag. Technol. ICIMTech 2019, vol. 1, no. August, pp. 477-481, 2019.

[29] I. Made, A. Citra, and W. Hadi Nasbey, "Improvement of Learning Process and Learning Outcomes in Physics Learning by using Collaborative Learning Model of Group Investigation at High School (grade X, SMAN 14 Jakarta)," J. Educ. Pract., vol. 6 No 11, no. 11, pp. 75-80, 2015.

[30] O. Bin Majid, M. F. Hilmi, N. A. Rashid, S. M. Syed-Mohammad, N. Malim, and Z. Zainol, "Collaborative Learning Environment with Think-Pair-Share Method and Learning Tools for Learning Arabic Online,” Proc. - 2013 Taibah Univ. Int. Conf. Adv. Inf. Technol. Holy Quran Its Sci. NOORIC 2013, pp. 77-82, 2015.

[31] Á. Di Serio, M. B. Ibáñez, and C. D. Kloos, “Impact of an augmented reality system on students' motivation for a visual art course,” Comput. Educ., vol. 68, pp. 586-596, 2013.

[32] Y. Hsu, "Exploring the Learning Motivation and Effectiveness of Applying Virtual Reality to High School Mathematics,” Univers. J. Educ. Res., vol. 8, no. 2, pp. 438444, 2020.

[33] F. J. Detmer, J. Hettig, D. Schindele, M. Schostak, and C. Hansen, "Virtual and Augmented Reality Systems for Renal Interventions: A Systematic Review,” IEEE Rev. Biomed. Eng., vol. 10, pp. 78-94, 2017.

[34] D. Allcoat and A. von Mühlenen, "Learning in virtual reality: Effects on performance, emotion and engagement," Res. Learn. Technol., vol. 26, no. 1063519, pp. 1-13, 2018.

[35] K. T. Huang, C. Ball, J. Francis, R. Ratan, J. Boumis, and J. Fordham, "Augmented versus virtual reality in education: An exploratory study examining science knowledge retention when using augmented reality/virtual reality mobile applications," Cyberpsychology, Behav. Soc. Netw., vol. 22, no. 2, pp. 105-110, 2019.

[36] E. A.-L. Lee and K. W. Wong, “A Review of Using Virtual Reality for Learning," in Lecture Notes in Computer Science (including subseries Lecture Notes in Artificial Intelligence and Lecture Notes in Bioinformatics), vol. 5080 LNCS, 2008, pp. 231-241. 